\title{
Effects of climate change on cherry production in Naoussa, Greece and Bonn, Germany: adaptation strategies
}

\author{
P. Drogoudi ${ }^{1}$ K. Kazantzis ${ }^{1} \cdot$ Achim Kunz $^{2} \cdot$ Michael M. Blanke ${ }^{2}$ (D)
}

Received: 4 September 2019 / Accepted: 10 February 2020 / Published online: 31 March 2020

(c) The Author(s) 2020

\begin{abstract}
The aim of the present study was to identify sweet cherry varieties and growing regions that are resilient to climate change as well as strategies for mitigating the effects of climate change on sweet cherry production in a Northern European location (Meckenheim, Germany) and a Southern European location (Naoussa, Imathia, Greece). Sweet cherry was chosen for this study as it is sensitive to reduced chill accumulation (i.e., fewer chilling hours in winter) and to late frost damage caused by flower opening time advancement. Whereas initial predictions suggested that fruit growing in Southern Europe is particularly sensitive to climate change, our comparison of long-term records of both phenological (flowering) data and weather (frost, temperature) at both locations indicated the opposite. The annual mean temperature in Naoussa increased during 1984-2018 by $1.6^{\circ} \mathrm{C}$ to $15.8{ }^{\circ} \mathrm{C}$, whereas it increased during $1958-2018$ by $1.5^{\circ} \mathrm{C}$ to $9.8^{\circ} \mathrm{C}$ in Meckenheim. In Naoussa, flowering was found to have advanced by 6.7 days in the late-flowering cherry cultivar 'Tragana Edessis,' but by as much as 8.3 days in the early flowering 'B. Burlat,' 1.5 days in 'Vogue,' and 3.2 days 'Larian' over the last 35 years (1984-2019). In the temperate climate of the Meckenheim cherry-growing area, flowering advanced by 14.1 days during the period 1978-2019 in the early flowering and early maturing cultivar 'B. Burlat,' such that it now coincides with the late spring frost. This flowering advancement in Meckenheim was almost twice that observed for 'B. Burlat' cherries in Naoussa. Thus, in contrast to what was previously thought, cherries grown in Naoussa may be more resilient to climate change due to the essentially frost-free climate during and after cherry flowering and the occurrence of sufficient chilling hours during winter. This strength may enable Imathia to export sweet cherries to Northern Europe in May, a time of the year when the fruit of this region is not yet available. By contrast, sweet cherry production in the colder climate at Meckenhein shows greater lowering advancement is more susceptible to frost (and therefore requires frost protection technology), making it less resilient to climate change.
\end{abstract}

Keywords Chilling $\cdot$ Climate resilience $\cdot$ Flower $\cdot$ Frost $\cdot$ Fruit tree $\cdot$ Phenology $\cdot$ Prunus avium L.

Communicated by Elena Xoplaki, Guest Editor.

Michael M. Blanke

mmblanke@uni-bonn.de

P. Drogoudi

drogoudi@otenet.gr

1 Department of Deciduous Fruit Trees (DDFT) in Naoussa, Institute of Plant Breeding and Genetic Resources, Hellenic Agricultural Organization (HAO) 'Demeter', 38 R.R. Station, 59035 Naoussa, Greece

2 INRES-Horticultural Science, University of Bonn, Auf dem Hüegel 6, 53121 Bonn, Germany

\section{Introduction}

The Mediterranean area, including Greece, is of the regions most affected by recent climate change: it has experienced a combination of increasing temperatures and declining precipitation (Xoplaki 2020). On the other hand, Germany, with its milder winters and constant precipitation (e.g., ca. 605 mm in Bonn; Blanke and Kunz 2009b), has been less affected by climate change. The five major effects of recent climate change on fruit trees, particularly in the Mediterranean region, include flowering advancement and reduced winter chill accumulation (a significant number of chill hours are required to initiate flowering in some fruit species) due to warmer winters, as well as heat, drought, and heavy storms during fruit development in the summer. 
Plant phenological events fluctuate from year to year and are strongly influenced by variations in environmental factors such as temperature. Long-term records of phenological data are valuable as they can be used to estimate the influence of climate variations on plant development and the timing of life cycles (Blanke and Kunz 2009a). A trend for the gradual advancement of bloom dates of temperate-zone trees over the years has been observed in historical records (Blanke and Kunz 2009b). This may be due to reduced chill accumulation during the winter, as originally postulated for cherries in the continental climate of Germany (Luedeling et al. 2013), a reduction in cold days in winter (Kaufmann and Blanke 2018), and a longer subsequent warming/forcing period (Kaufmann and Blanke 2019).

In the present study, climate data (days with frost, chill accumulation, temperatures, and precipitation) and phenological data on the flowering of commercially cultivated cherry cultivars in a Northern European location (Meckenheim, Germany) and a Southern European location (Naoussa, Imathia, Greece) were examined in order to identify sweet cherry varieties and growing regions that are resilient to climate change as well as strategies for mitigating the effects of climate change on sweet cherry production.

\section{Materials and methods}

\section{Climate data acquisition}

Climate data such as daily temperatures, yearly precipitation, and days with frost were collected for the Institute of Plant Breeding and Genetic Resources in the Department of Deciduous Fruit Trees in Naoussa, along with flower opening date (i.e., the earliest date when $10 \%$ of the flowers are open) records for cherry cultivars grown there. The Naoussa site is located at ca. $40^{\circ} \mathrm{N}$ and at an altitude of $119 \mathrm{~m}$, and has a Mediterranean climate with less rain during the summer months and $690 \mathrm{~mm}$ of rainfall annually (Table 1). Daily minimum and maximum temperatures were recorded for the period 1980-2019 at an on-site meteorological station. Frost incidence was recorded as the number of days with a minimum temperature below $0{ }^{\circ} \mathrm{C}$ in March, April, and May. Data obtained for Naoussa were compared with corresponding data obtained for the Klein-Altendorf experimental station at a latitude of $50^{\circ} \mathrm{N}$ and an altitude of ca. $170 \mathrm{~m}$ in the Meckenheim fruit/cherry-growing region (Luedeling et al. 2011; Blanke and Kunz 2009b). The Meckenheim site is exposed to maritime Westerly Atlantic winds, but is buffered from them by the Rhine Valley (Kaufmann and Blanke 2017).
Table 1 Comparison of the climate at Naoussa, Greece (during the period 1984-2018) to that at Meckenheim, Germany (during the period 1958-2018)

\begin{tabular}{lll}
\hline Parameter & Naoussa & Meckenheim \\
\hline Latitude & $40^{\circ} \mathrm{N}$ & $50-51^{\circ} \mathrm{N}$ \\
Altitude & $119 \mathrm{~m}$ & $170 \mathrm{~m}$ \\
Annual mean temperature & $15.8^{\circ} \mathrm{C}$ & $9.8^{\circ} \mathrm{C}$ \\
Precipitation & $690 \mathrm{~mm}$ (mainly in & $605 \mathrm{~mm}$ (even- \\
& the winter months) & $\begin{array}{l}\text { year distribu- } \\
\text { tion) }\end{array}$ \\
Chilling hours until 1 Feb & $1100-1300$ & $950-1350$ \\
$\begin{array}{c}\text { Typical flower opening date } \\
\text { of the cherry cv. 'Burlat' }\end{array}$ & 30 March & 15 April \\
\hline
\end{tabular}

\section{Calculating the chill accumulation}

The number of chilling hours during the winter at each site was calculated according to three models, including the simple but popular Weinberger chilling hours model, which sums the hours during which the temperature was between $0^{\circ}$ and $7.2{ }^{\circ} \mathrm{C}$.

\section{Phenological data: flower opening date according to the BBCH scale}

The flower opening date was recorded between 1984 and 2019 for trees of the cherry cultivars 'Tragana Edessis,' 'B. Burlat,' 'Larian,' and 'Vogue' maintained at the Department of Deciduous Fruit Trees in Naoussa. Flower opening dates were also recorded for the cultivar ' $\mathrm{B}$. Burlat' at the Klein-Altendorf experimental station in Meckenheim between 1975 and 2019 (Blanke and Kunz 2009b). Flower opening dates (F1/BBCH 61) were originally evaluated based on the Baggiolini scale (Lichou et al. 1990; Baggiolini 1952), but they were subsequently derived based on the BBCH scale (Meier et al. 1994) and then internationally harmonized for cherry (Wenden et al. 2017). New cherry trees were planted successively to ensure that trees of an appropriate age were available at all times. Phenological records of fully grown cherry-bearing trees grafted onto Mazzard and trained into a vase shape at Naoussa were obtained, as were those of trees that were grafted onto GiSelA5 and trained into a slender spindle at Meckenheim.

\section{Statistical data processing}

Pearson correlation analysis was performed between annual change in the long-term mean temperature and the 
year as well as between flower opening date and temperature using SPSS v.24 (SPSS Inc., Chicago, IL, USA).

\section{Results and discussion}

\section{Frost incidence and changes in annual mean temperature and precipitation}

In Naoussa, the frost incidence during March has decreased dramatically (from 4.8 to 1.3 days) over the last 30 years, and frost has been essentially nonexistent in April during that period (Table 2). Hence, increased frost damage due to climate change does not appear to be a problem for crops grown in this region of Northern Greece. However, in Meckenheim, there is a risk of frost in the period from March to May-a period that coincides with advanced cherry flowering at the end of March or early April, meaning that frost is presenting an increasing risk to cherry production in Meckenheim.

Analysis of the last 34 years (1984-2018) of climate data for the Naoussa region in Northern Greece showed an increase in the annual mean temperature $T_{\text {mean }}$ of $1.6^{\circ} \mathrm{C}$ over that period but no significant change in annual precipitation $(690 \pm 26 \mathrm{~mm}$; mean $\pm \mathrm{SE}$ for the 34-year period). Similarly, analysis of the last 39 years of climate data for the Meckenheim growing region of Germany showed an increase in $T_{\text {mean }}$ of $1.5{ }^{\circ} \mathrm{C}$ over that period but no significant change in annual precipitation $(605 \pm 8 \mathrm{~mm}$; mean \pm SE).

Table 2 Frost incidence (the average number of days with frost, i.e., with the minimum temperature below $0{ }^{\circ} \mathrm{C}$ ) per month at Naoussa from 1984 to 2019 and at Meckenheim from 1958 to 2019 (utilizing data from Blanke and Kunz 2009b)

\begin{tabular}{lllll}
\hline & Period & March & April & May \\
\hline Naoussa & $1984-2000$ & 4.8 & 0.5 & 0 \\
& $2001-2019$ & 1.3 & 0.3 & 0 \\
Meckenheim & $1958-2019$ & 4.4 & 2.5 & 0.4 \\
& $1958-1987$ & 5.0 & 2.5 & 0.5 \\
& $1988-2019$ & 3.8 & 2.8 & 0.3 \\
\hline
\end{tabular}

\section{Chilling hours}

Predictions for Mediterranean countries in general (Luedeling et al. 2013), and Greece in particular, suggest that the number of winter chilling hours will decrease, leading to issues with flowering in fruit crops that require significant chill accumulation ('high-chill crops'), such as sweet cherry and-to a lesser extent-European plum and apple. However, it appears that the winter chilling requirements of the cherry cultivars grown in the hills of Imathia are still being satisfied in most years, since flowering abnormalities are yet to be documented in Naoussa for any cultivar. Moreover, 'Ferrovia' - a high-chill cultivar-regularly bears flowers and fruit in Northern Greece.

Similarly, the chilling requirements of cherry cultivars are still being satisfied in the temperate continental climate of the Meckenheim fruit-growing region in most years (Table 3), even for high-chill cultivars such as 'Schneiders späte Knorpelkirsche' (Kaufmann and Blanke 2018). Chill accumulation may even improve as winters become warmer, as there will be fewer winter days with subzero temperatures and more chilly days (Luedeling et al. 2011).

\section{Flowering advancement: less in Naoussa than in Meckenheim}

Flowering, a prerequisite for fruit set, is affected by climate change due to the impact of climate change on chill accumulation and the number and timing of days with frost. Frost does not appear to threaten cherry flowering in Naoussa since the incidence of frost has decreased in recent years. The main effect of climate change in Naoussa appears to be less favorable conditions for pollination during flowering. Over the period 1984-2019, the flower opening date advanced by 6.7 days for 'Tragana Edessis' during the period, 8.3 days for 'B. Burlat,' 1.5 days for 'Vogue,' and 3.2 days for 'Larian' (Fig. 1; Table 4).

The advancement in the flower opening date seen for the cultivar 'Burlat' in Meckenheim 14.1 days, which should be compared with the flower opening date advancement of 8.3 days across a similar period (1984-2019) for 'Burlat' in Naoussa. Figure 1a highlights the greater flowering advancement of the cultivar 'Burlat' at Meckenheim than at Naoussa, given that the slope of the linear curve
Table 3 Mean chill accumulation at Meckenheim (after Luedeling et al. 2011), as calculated using 60 years (1958-2018) of climate data for this region and three different models

\begin{tabular}{llll}
\hline Period & $\begin{array}{l}\text { Chilling hours }(\mathrm{CH}) \text { from } \\
\text { chilling hours model }\end{array}$ & $\begin{array}{l}\text { Chilling units }(\mathrm{CU}) \text { from } \\
\text { Utah model }\end{array}$ & $\begin{array}{l}\text { Chilling portions } \\
\text { (CP) from dynamic } \\
\text { model }\end{array}$ \\
\hline Up to 1st January & 955 & 1160 & 58.0 \\
Up to 1st February & 1356 & 1527 & 77.3 \\
Up to 1 March & 1727 & 1883 & 96.1 \\
\hline
\end{tabular}


(a) 'Burlat'-Bonn

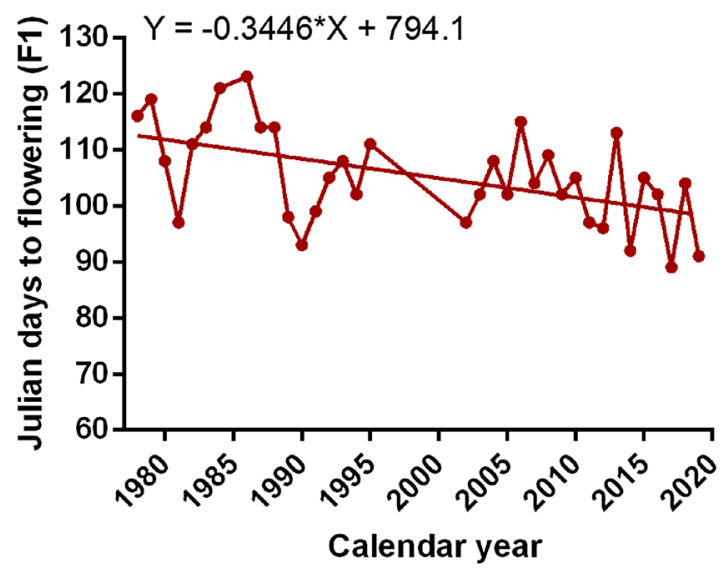

(c) 'Tragana Edessis'- Naoussa

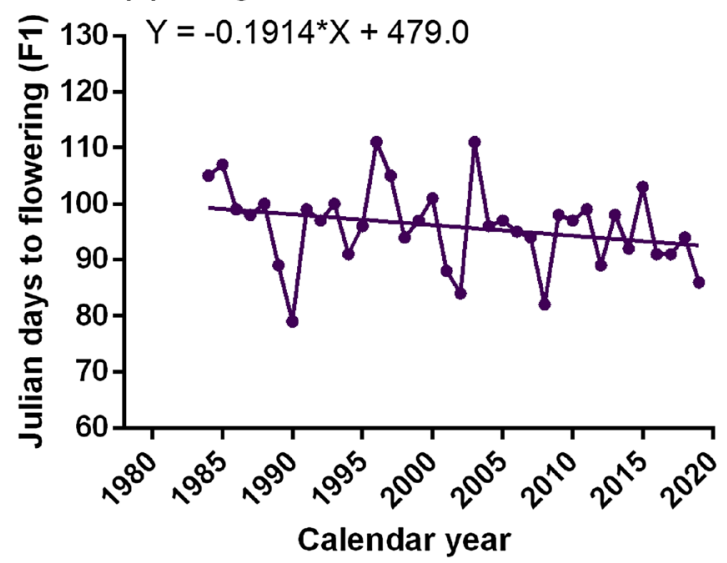

(b) 'Burlat'- Naoussa

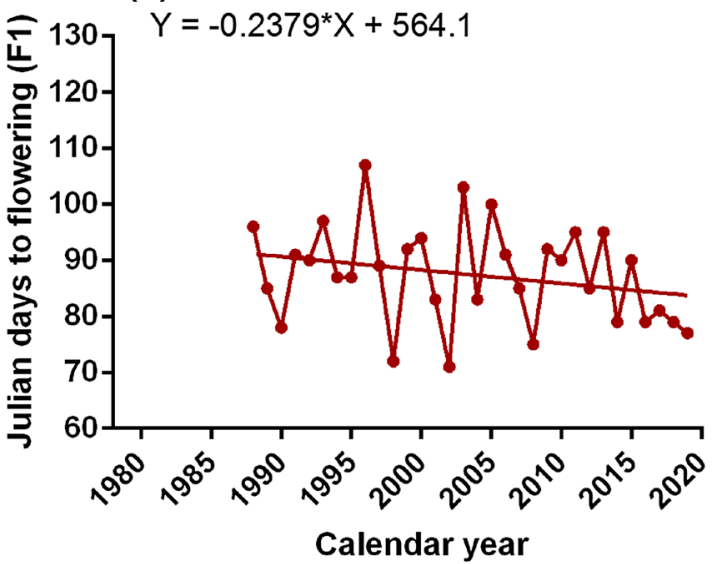

(d) 'Larian'- Naoussa

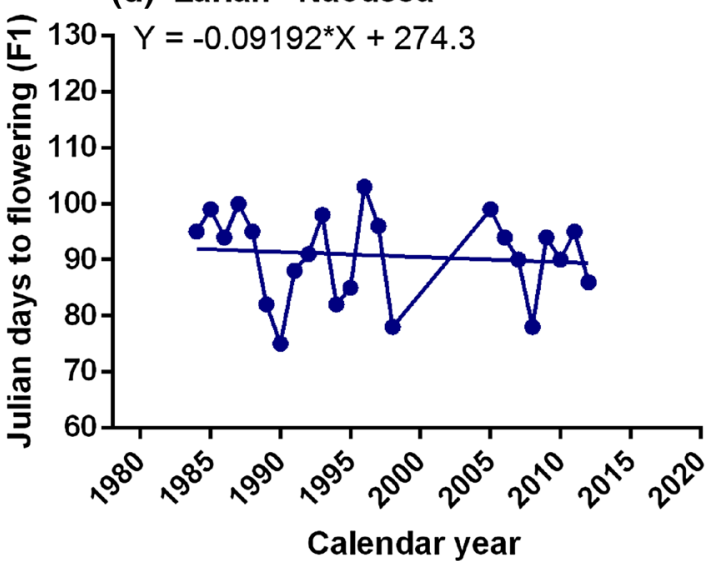

(e) 'Vogue'- Naoussa

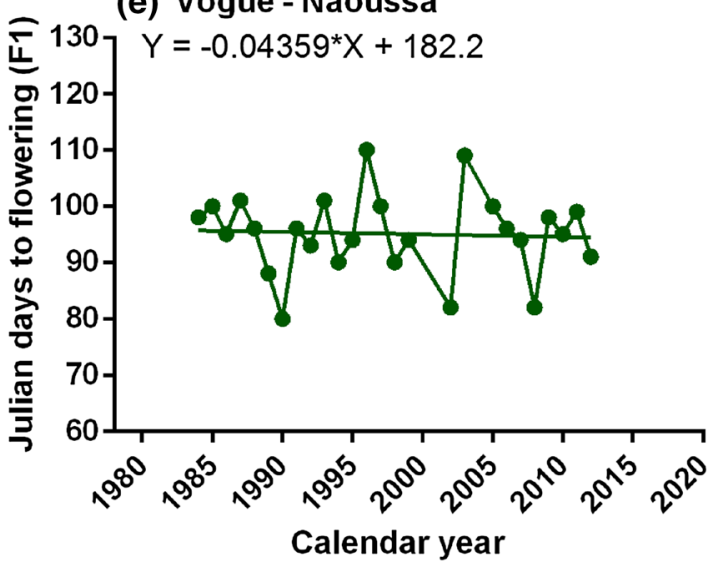

Fig. 1 Flower opening dates $(\mathrm{BBCH} 61 ; \mathrm{F} 1)$ for various cherry cultivars: a 'Burlat' at Meckenheim for the period 1978-2019; b 'Burlat,' c 'Tragana Edessis,' d 'Larian,' and e 'Vogue' at Naoussa during the

fit is -0.34 for the 'Burlat' data from Meckenheim and -0.24 for the 'Burlat' data from Naoussa. Indeed, the flower opening date advancement observed for the cherry trees at Meckenheim and both cvs 'B. Burlat' and 'Tragana E.' in Naoussa is comparable to the flower opening date period 1984-2019. Linear curve fitting was applied to each dataset (note that 1 April $=91$ Julian days; 15 April $=105$ Julian days)

advancement of 10 days observed for various apple cultivars at Meckenheim when data for the last 20 years were compared with data for the previous 30 years (Blanke and Kunz 2009b). 
Table 4 Changes in the flower opening dates (BBCH $61 ; \mathrm{F} 1)$ for various cherry cultivars in Naoussa and Meckenheim

\begin{tabular}{clllll}
\hline & Cultivar & Flowering period & $\begin{array}{l}\text { Flower opening date } \\
\text { then (in Julian days) }\end{array}$ & $\begin{array}{l}\text { Flower opening date } \\
\text { now (2002-2019) (in } \\
\text { Julian days) }\end{array}$ & $\begin{array}{l}\text { Differ- } \\
\text { ence } \\
\text { (days) }\end{array}$ \\
\hline Naoussa & 'Tragana E.' & Late & 99.3 & 92.6 & 6.7 \\
$\begin{array}{c}\text { (Northern } \\
\text { Greece) }\end{array}$ & 'Vogue' & Medium & 95.7 & 94.2 & 1.5 \\
$1984-2019$ & 'Burlat' & Early & 92.7 & 83.8 & 8.3 \\
& 'Larian' & Early & 91.9 & 88.7 & 3.2 \\
Meckenheim & 'Burlat' & Early & 112.5 & 98.4 & 14.1 \\
(Germany) & & & & & \\
$1984-2019$ & & & & & \\
\hline
\end{tabular}

\section{Cherry flowering and cultivation systems in Naoussa and Meckenheim}

In the Meckenheim growing area, cherries are often grown in open or closed polytunnels in order to (i) induce earlier yields, (ii) protect the trees from frequent spring frosts when they are flowering, and (iii) protect the trees from rain-induced cracking during the fruit maturation period (Fig. 2, photograph on right). In Naoussa, spring frosts only induce damage in early-flowering fruit crops such as apricots and peaches; cherries are not affected. However, very frequent rain in Naoussa during the fruit maturation period can induce fruit cracking in cherry trees, so rain shelters are increasingly being used for cherry trees, as they are at Meckenheim.

\section{Strategies for mitigating the effects of climate change on cherry production in Naoussa and Meckenheim}

Flowering is the most sensitive stage of fruit cultivation to climate change, as this stage is impacted by various effects of climate change, including (a) reduced winter chilling hours, (b) flower opening date advancement, and (c) an increased risk of late frosts during the flowering period (such that early flowering in Meckenheim now coincides with the frost), and (d) unfavorable pollination conditions, such as temperatures below $11{ }^{\circ} \mathrm{C}$ and rain (which are suppressing pollination by honeybees in Imathia). However, cherries grown in mountainous regions such as Naoussa in Northern Greece appear to be relatively resistant to the effects of climate change (compared to cherries grown in Meckenheim, for example) because there is sufficient chill accumulation during winter in most years and because late frosts during/after flowering are very rare.

Based on the results obtained in the present work, Tables 5 and 6 present mitigation strategies for the effects of climate change on cherry production in general (i.e., in all cherry-growing regions) and in Naoussa (Greece) and Meckenheim (Germany) in particular. Note that invasions of the cherry fly Drosophila suzukii, recently monitored as a result of the temperature elevation, in both fruit-growing regions require insect netting, however this is not easily applied.

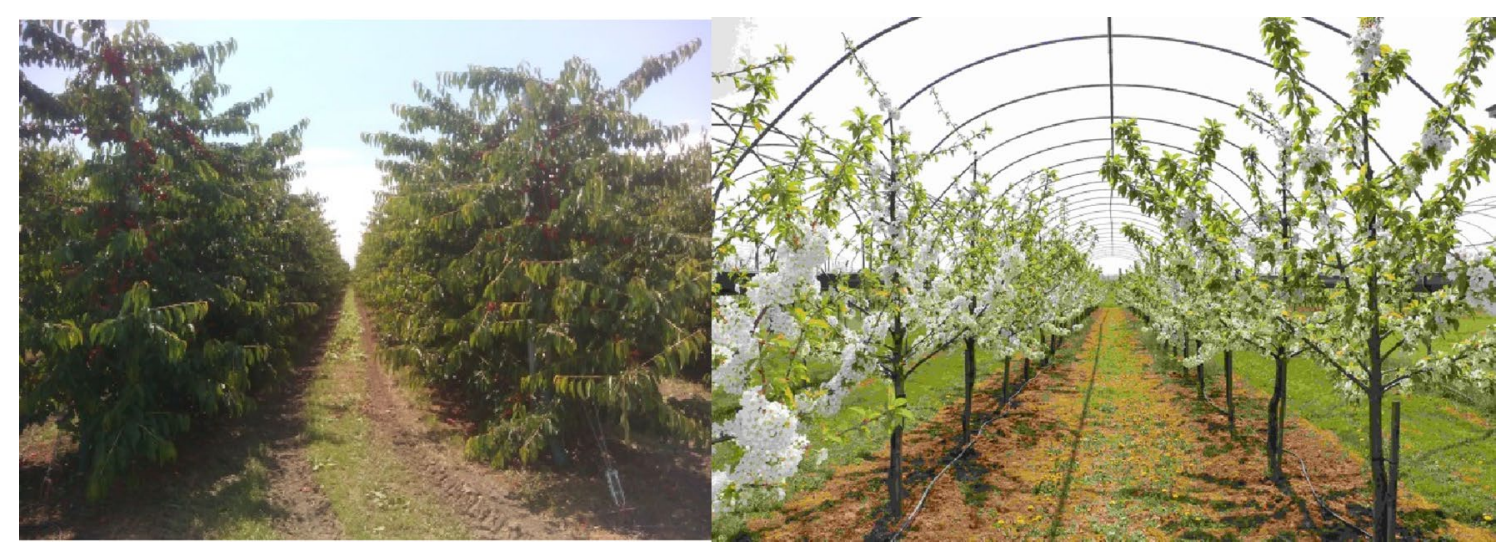

Fig. 2 Cherry cultivation without frost protection in Naoussa (photograph on left) and cherry cultivation under a plastic cover during the flowering period in Meckenheim (photograph on right) 
Table 5 General strategies for mitigating the effects of climate change on cherry production

\begin{tabular}{|c|c|c|c|}
\hline Season & Culpable weather pattern & Effect & Adaptation strategy \\
\hline Winter & Warm winter & Reduced chilling hours & $\begin{array}{l}\text { Relocate to high altitude/use culti- } \\
\text { vars with low chilling require- } \\
\text { ments }\end{array}$ \\
\hline Spring & Late frost & Flower damage & Use sprinklers/turbines/crop covers \\
\hline \multirow[t]{2}{*}{ Summer } & Heat and drought & Soft fruit and fruit fall & Evaporative cooling \\
\hline & Rainfall & Fruit cracking & Use rain protection shelters \\
\hline
\end{tabular}

Table 6 Comparison of strategies used to mitigate the effects of climate change on cherry production in Naoussa (Greece) and Meckenheim (Germany)

\begin{tabular}{|c|c|c|}
\hline Effect of climate change & Naoussa & Meckenheim \\
\hline $\begin{array}{l}\text { Invasions of the cherry fly } \\
\text { Drosophila suzukii }\end{array}$ & Insect net & Insect net \\
\hline Reduced chilling hours & - & - \\
\hline Frost & - & Frost protection \\
\hline Pollination problems & Bumble bee hive & Bumble bee hive \\
\hline Rain during fruit maturation & Rain shelter & Rain shelter \\
\hline
\end{tabular}

\section{Conclusions}

Based on the results obtained in this work, fruit-growing regions in the Mediterranean that are mountainous (and thus have cool winters with sufficient chilling hours) may be relatively resilient to climate change, given that frosts during the flowering season have been very rare in the Naoussa region of Greece over the past 30 years. These regions may still need to adopt a few climate change adaptation strategies or to switch to medium-chill fruit varieties. On the other hand, due to increasingly early flowering in the Meckenheim fruitgrowing region of Germany and the occurrence of late frosts in this region, a frost protection strategy is now required during the flowering season in Meckenheim.

Acknowledgements Open Access funding is provided by the German Projekt DEAL. We are grateful to Mrs A. Giannina for providing the historical climate records for Naoussa, Imathia (Northern Greece) and Mr. H. Walbröhl for taking the daily climate records since 1958 in Klein-Altendorf, University of Bonn (Germany), and to Professor Elena Xoplaki for editorial guidance.

Funding There was no external funding of this work.

\section{Compliance with ethical standards}

Conflict of interest The authors declare no conflict of interest.

Open Access This article is licensed under a Creative Commons Attribution 4.0 International License, which permits use, sharing, adaptation, distribution and reproduction in any medium or format, as long as you give appropriate credit to the original author(s) and the source, provide a link to the Creative Commons licence, and indicate if changes were made. The images or other third party material in this article are included in the article's Creative Commons licence, unless indicated otherwise in a credit line to the material. If material is not included in the article's Creative Commons licence and your intended use is not permitted by statutory regulation or exceeds the permitted use, you will need to obtain permission directly from the copyright holder. To view a copy of this licence, visit http://creativecommons.org/licenses/by/4.0/.

\section{References}

Baggiolini M (1952) Stade reperes du pecher. Revue Romande d'Agriculture. Vitic Aboric 4:29

Blanke MM, Kunz A (2009a) Misconceptions about the effects of climate change on horticulture. Proc Benelux Horticult Soc Annu Meeting, Gembloux, Belgium, p 12. http://www.beneluxshs.eu/ index.html. Accessed 3 Apr 2009

Blanke MM, Kunz A (2009b) Effects of climate change on pome fruit phenology at Klein-Altendorf [Auswirkungen rezenter Klimaveränderungen auf die Phänologie von Kernobst am Standort Klein-Altendorf]. Erwerbs-Obstbau 51:101-114 (special edition on climate change)

Kaufmann H, Blanke MM (2017) Performance of three numerical models to assess winter chill in fruit trees-a case study using cherry as model crop in Germany. Reg Environ Change 17:1-9

Kaufmann H, Blanke MM (2018) Substitution of winter chilling by spring forcing for flowering of sweet cherry? Sci Hortic (Amsterdam) 244:75-81

Kaufmann H, Blanke MM (2019) Chilling requirements of Mediterranean fruit crops in a changing climate. Acta Hortic 1242:275-280

Lichou J, Edin M, Tronel C, Sounier R (1990) Le cerisier. CTIFL, Paris

Luedeling E, Kunz A, Blanke MM (2011) More chilling for fruit trees in warmer winters [Mehr Chilling für Obstbäume in wärmeren Wintern]? Erwerbs-Obstbau 53:145-155

Luedeling E, Kunz A, Blanke MM (2013) Identification of chilling and heat requirements of cherry trees-a statistical approach. Int J Biometeorol 57:679-689

Meier U et al (1994) Phänologische Entwicklungsstadien des Kernobstes (Malus domestica Borkh. und Pyrus communis L.). des Steinobstes (Prunus-Arten). der Johannisbeere (Ribes-Arten) und der Erdbeere (Fragaria x ananassa Duch.). Nachr Dtsch Pflanzenschutzd 46:141-153

Wenden B et al (2017) Harmonisation of phenology stages. Acta Hortic 1162:9-12

Xoplaki E (2020) Climate and environmental changes in the Med region (MEDECC). Euro-Mediterr J Environ Integr (volume: 5) 